\title{
ストレッサーとしての対人葛藤 ーストレス低減方略への展望一
}

\author{
橋 本剛 \\ 名古屋大学
}

\section{要 約}

社会心理学における対人葛藤研究は, 問題解決を目的としたものが主流であり, その際に生じる心理的ストレ スとその解決については十分な議論がなされていない。一方, 健康心理学においても対人葛藤はストレッサーと して想定されてはいるが, 多くのストレッサーのうちのひとつとして, その特殊性はあまり考慮されてこなかっ た。そこで本論文でば,この 2 つ領域における対人葛藤とその対処方略の知見を概略的にレビューし, それ らを統合した枠組みで研究を発展させることを提唱した。また, 同じく対人関係において生起しながらも, 精 神的健康にポジティブな影響を与える変数であるソーシャルサポートと対人葛藤との関連についても考察した。 さらに，ストレッサーとしての対人葛藤研究における今後の具体的な課題として，(1) ストレッサーとしての対 人葛藤の影響力，(2) 対人葛藤対処方略のストレス低減可能性，(3)ソーシャルサポートと対人葛藤との関連など を挙げ，それらの課題を検証するための概念的なモデルについて考察し，ネガティブな影響を及汸す対人関係 を，偶発性を含んだライフイベントと，比較的安定した対人認知の一側面とに弁別する必要性を提唱した。

キーワード：対人葛藤, ストレッサー, 解決（対処）方略, 心理社会的ストレスの認知的評価・対処理論, ソー シャルサポート

\section{I. はじめに}

人間にとって最も重要なもののひとつである他者との 関わりは，人間にとって最も煩わしいことのひとつでも あるという矛盾は古くから言われてきたことであり, 近 代に端を発する社会科学のひとつである心理学にとって も重要なテーマとして考えられてきた。その中でも人間 関係の中で生じる典型的な問題である対人的葛藤事態に ついては, おもに社会心理学の分野で膨大な量の研究が 蓄積され, 葛藤解決のための有効な知見を数多く提供し ている。ただ,これらの研究の多くは状況を統制した， いわゆる実験社会心理学的手法を用いて行われたもので あり, 論理が明確であるという長所とともに, 現実場面 にどの程度応用可能かが不明膫であるという短所も持ち あわせている。

また, 社会心理学における対人葛藤対処研究はその問
題解決のみに焦点があてられているが, 現実場面におい ては解決不可能な葛藤, ストレスフルな解決方略を用い ざるを得ない葛藤も稀ではない。そのときには, 問題解 決だけを従属変数とした研究では捉えきれないストレス 反応が顕在化することも推測される。

一方, 健康心理学においては, 心理的ストレスを「人 間と環境との間の特定な関係であり, その関係とは, そ の人の資源に負担をかけたり, 資源の許容範囲を越えた り，幸福を脅かしたりすると評価されるものである」と 定義した Lazarus \& Folkman（1984）の心理社会的ス トレスの認知的評価・対処理論が, 今日の心理的ストレ ス研究の基礎理論として，大きな役割を果たしている。 その中で彼らはストレス対処方略を大きく問題焦点型対 処と情動焦点型対処に分類している。問題焦点型対処と は, 問題の所在を明らかにしていくことに向けられたり, いくつかの解決策を当てはめてみたり, そのような解決 
策を用いることによってもたらされる利益や損益を秤に かけてみたり, それらの解決策の中からいくつかのもの を選び出して実際に試してみたりする, 問題を解决する ための対処のことである。一方, 情動焦点型対処とは, 問題の回避や過小評価, もしくは注意をそらしたり問題 に肯定的な価値を見いだすなどして，情動的に苦痛を低 減させるためになされる対処のことである。そして,こ れらの対処方略は対人的葛藤事態というストレッサーに 対しても適用可能であると考えられる。

しかし，多くの心理的ストレス研究はストレッサーを 包括的に捉える傾向があり，個々のストレッサーの特性 を考慮した対処方略研究は多くはない。ましてや対人的 葛藤事態をストレッサーとして考元た際には, 個人の自 己資源や対処能力のみならず, 葛藤のターゲットとの相 互作用も無視するわけにはいかないので, 個人内のみの ストレス低減過程を考慮するだけでは限界が生じること となる。しかし, 対人関係のストレスが日常生活におい て最もストレスフルなもののひとつである（浦，1992） 以上, その解決とそこで生じるストレスの低減に有効な 対処方略を議論するのは必要なことである。そこで本論 文では, 対人葛藤に対する対処方略について社会心理学 と健康心理学のそれぞれの知見を概略的にレビューした 上で, 今後, この 2 つの領域をグローバルに捉えた対処 方略研究への展望を討論することを目的とする。また, 同じく対人関係に起因するものの, そのストレス反応に 対する影響力は逆方向であるソーシャルサポートと対人 葛藤との関係についても考察する。

\section{II. 社会心理学における対人葛藤解決方略研究}

\section{1. 対人葛藤解決方略研究の基碟}

社会的相互作用に重点をおく社会心理学の研究におい ては, 対人的暮藤事態についても, 当事者間の実際の葛 藤解決を従属変数として扱う研究に終始するのが通例で あった。言うまでもなく, それらの研究は非常に有意義 な知見を提供してきたが, その一方で, 従属変数として の情動についての議論をおろそかにしてきたことも否め ないであろう。

ところで，1971年に刊行された年報社会心理学第12号 では, 葛藤と紛争が特集され, 多くの葛藤状況とともに 対人葛藤に関してもさまざまな議論が展開されている。 その中でも池内（1971）による社会心理学における葛藤 研究のレビューは簡潔明瞭なものであり, かつ対処方略 について考える際にも重要な知見を提供するものである。

社会心理学における対人葛藤の基礎的理論を把握する ためにこのレビューを概観すると, まず彼は, Mack \&
Snyder（1957）を簡略にまとめ, 葛藤行動, 葛藤関係な ぞによって葛藤事象を記述し，その疑問点を指摘した。 その際, 彼は葛藤行動が行われる葛藤関係と葛藤行動が 行われない葛藤関係の存在, さらにこの関係を当事者の 両方が結ぶ場合と一方のみが結ぶ場合の存在を示唆して いる。これらのことは葛藤対処方略にも影響を及ほすす重 要な要因である。なぜなら, 葛藤行動（非難, 陰口, 暴 力など）が行われており，かつ両者がこの関係を結んで いる場合には葛藤関係が明確に意識され，葛藤関係にあ る両者ともに対処方略の必要性を意識し, 対処方略の相 互作用も生じ得る。しかし，葛藤行動が行われなかった り，葛藤関係が一方向性のものだとすると，対処方略の 実行が困難であったり，そもそも対処方略が必要なのか という疑問が生じることになるからである。この点に関 連して，池内（1971）は実験的に葛藤を生じそうな場面 に被験者を追い込んでも, 彼らの間に期待されるほどの 葛藤が生じないことも述べているが，これは葛藤が潜在 的にはあってもなかなか顕在化されない典型的な例であ る。そして，このようにストレスフルな状況であるにも かかわらず，状況を変容するための行動を行う必然性が 見いだせないときに，問題焦点型対処でなく情動焦点型 対処が必要となることが予測されるが，この点に関して は後述する。次に，葛藤が社会的システムの産物であり， 葛藤の成立には，いつも家庭や組織や種族が持つ，規範 や価值体系や文化が介在していることが指摘されている。 この点は環境よりも主体の内的要因を重視する傾向のあ る今日の心理社会的ストレス研究も十分考慮すべきであ ろう。さらに葛藤の分類（「課題志向的葛藤」と「人格志 向的葛藤」），葛藤の過程（潜在的，一過的，慢性的，進 行的），そして葛藤解決の類型（当事者の一方による他 方の征服, 他方をせん滅することによる一方の独占, 双 方の破滅によるシステムの破壊，両者関係の再編成によ るシステムの再編成，係争問題の暫定的処理，当事者間 の関係解消）といった葛藤研究におりる基礎理論が提示 されている。

\section{2. 対人葛藤解決方略研究の現状と課題}

その後, 葛藤の形成や拡大過程に比べて, 解決過程の 研究が少ないことが指摘され（藤森・藤森，1992），対人 葛藤事態における解決方略研究に, 次元を想定したさま ざまな類型化が登場した（梶田，1988；Falbo \& Peplau， 1980 ：Sillars，1980：藤森，1987；1989；吉野，1987)。 また, 解決方略の測定尺度を作成する際にも対処方略 の類型化の試みが行われている (Kilmann \& Thomas, 1977 ; Rahim, 1983)。Table 1 に示されているこれらの 類型はいずれも葛藤対象の主張を排斥するか受容する 
橋本：ストレッサーとしての対人葛藤

Table 1

対人葛藤解決方略の次元と類型

\begin{tabular}{|c|c|c|c|c|c|}
\hline $\begin{array}{l}\text { Falbo \& Peplau (1980) } \\
\text { Sillars }(1980) \\
\text { 藤森 }(1987 ; 1989) \\
\end{array}$ & \multicolumn{3}{|c|}{$\begin{array}{l}\text { 直接一間接 } \\
\text { 情報交換の促進一抑制 } \\
\text { コミュニケーションの促進一抑制 }\end{array}$} & \multicolumn{2}{|c|}{$\begin{array}{l}\text { 一方向一双方向 } \\
\text { 個人解決一相互解决 } \\
\text { 個別的解决一協調的解決 }\end{array}$} \\
\hline \multicolumn{6}{|l|}{ 〈類型〉 } \\
\hline $\begin{array}{l}\text { 梶田 (1988) } \\
\text { 吉野 (1987) }\end{array}$ & $\begin{array}{l}\text { 他譲志向、 } \\
\text { 強硬型、 }\end{array}$ & $\begin{array}{l}\text { 方向探索、 } \\
\text { 柔軟型、 }\end{array}$ & $\begin{array}{l}\text { 状況離脱志向、 } \\
\text { 放置型 }\end{array}$ & 無譲志向、 & 自譲志向 \\
\hline 藤森 $(1987 ; 1989)$ & 個別型、 & 統合型、 & 回避型、 & 同調型 & \\
\hline $\begin{array}{l}\text { Kilmann \& Thomas (1977) } \\
\text { Rahim (1983) }\end{array}$ & $\begin{array}{l}\text { 競合型、 } \\
\text { 支配型、 }\end{array}$ & $\begin{array}{l}\text { 協同型、 } \\
\text { 統合型、 }\end{array}$ & $\begin{array}{l}\text { 回避型、 } \\
\text { 回避型、 }\end{array}$ & $\begin{array}{l}\text { 妥協型、 } \\
\text { 妥協型、 }\end{array}$ & $\begin{array}{l}\text { 順応型 } \\
\text { 従属型 }\end{array}$ \\
\hline
\end{tabular}

かという次元, 葛藤の解決に積極的か消極的かという次 元の兼ね合いで弁別されており, 大まかにはかなり類似 したものであると考えられる。その意味で, 藤森・藤森 （1992）に上る競争的／協同的次元とコミュニケーショ ンの促進／抑制次元の 2 次元・4象限の分類は妥当であ ろう。しかし，いずれの方略も葛藤をいかに解決するか という対処方略であり，したがって従属変数としては葛 藤の解決度を用いるのが一般的である。このことは, 対 人葛藤をストレッサーとして考えたときに，その対処方 略として問題焦点型対処しか想定しておらず，情動焦点 型対処が視野に含まれていないという事実を示唆してい る。実際, 従属変数としてストレス反応を設定している 研究の少なさはこのことを裏付けている。さらに，わが 国においては具体的な事例研究が多いためか，Hoskins (1978)，Rahim (1983)，Warehime \& Lowe (1983) な どにみられるような対人葛藤に関する尺度作成の試みが あまりなされていない。この点も，今後のストレッサー としての対人葛藤研究の課題のひとつと考兄られる。ま た，かなり実験的ではあるが，葛藤事態における対処に 関して多くの知見を提供しているものとして，社会的ジ レンマの研究（山岸，1990など）がある。この分野に関 するレビューは今回は省略するが，ひとつ例を挙げると， Braver \& Rohrer（1978）は囚人のジレンマゲームにお いて, 利益の獲得に高く動機づけられた直接ゲーム参加 者と,そのゲーム観察者という 2 種類の被験者を設定し ている。そして直接ゲーム参加者と対戦したサクラが協 同を強化し，競争を罰するというしっぺ返し戦略を用い た後，参加者と観察者はそれぞれ別のゲームを実施し た。その結果，前者は自己の戦略を変更できずに競争的 であったのに対し，後者は観察した経験を生かして，よ り協同的な戦略を用いる傾向を示した。つまり，対人葛 藤の低減に向けて適切な対処を行うのに, 代理経験（第
三者的な立場）は直接経験（葛藤の当事者的な立場）よ り優れていることが導き出されたわけだが，このことは， 後に述べるソーシャルサポートの, 対処方略としての有 効性を示唆しているものとも考光られよう。つまり，第 三者が葛藤の解決法を提案すること, もしくはその具体 的な解決方略を実行することは，ソーシャルサポート研 究で言うところの情報的サポート, 道具的サポートに他 ならない。そして, 冷静な判断ができない葛藤の当事者 よりは，冷静な第三者の方が葛藤の解決に向けて，より 優れた判断ができるとするこの研究の知見は, 情報的サ ポート，もしくは道具的サポートが対人葛藤事態におい て，その解決に有効であるとも解釈できるのである。

\section{III. 健康心理学における対人葛藤解決方略研究}

\section{1. 心理社会的ストレス研究における対人葛藤}

健康心理学とは健康の推進・維持, 疾病の予防・治療, 健康・疾病・機能不全に関する病因学的及び診断学的に みた相互関係, さらにへルス・ケア・システムと健康政 策の策定の分析と改善に対する心理学領域の特定の教育 的，科学的，専門的貢献のすべてを包含したものである (本明, 1990)。したがって，その研究には必ず身体もし くは精神的健康に関する概念が導入されており, 心理社 会的ストレスの生起過程についての詳細な議論もなされ ている。しかし, 直接的にはメンタルヘルスに関与しな いと考えられる側面に関しては, 他の学問領域の知見を 活用する必要があるのも事実である。

健康心理学の分野に扔いては, 心理社会的ストレス研 究の文脈で対人関係がストレッサーとなる可能性は少な からず指摘されている (Rook, 1984 ; Tilden \& Galyen, 1987 ; Last, Barlow, \& O’Brien, 1984 ; 嶋, 1992 ; 大 迫，1994）。しかしながら，個人が体験するストレスを 包括的に捉えることが主流となっている現在の研究では, 
個々のストレッサーに特有の性質を考慮することの困難 さから，ストレッサーの種類を弁別した上でそれぞれの 対処方略を検討するようなストレス対処方略研究はあ まり行われていないのが現状である。しかし, Holmes \& Rahe (1967) が各種のストレッサーの持つインパク トを相対的に得点化したように，ストレッサー個々の持 つ影響力は違うと考えるのは自然なことである。もちろ ん, Lazarus \& Folkman (1984) の理論のように, スト レッサーのインパクトは個人によってかなり違うのも事 実であるが，一方，個人の資源にかかわらずほとんどの 人にとってインパクトを持つストレッサーが存在するの も事実なのである。ちなみに八尋・井上・野沢 (1993) は Holmes \& Rahe（1967）の社会的再適応評価尺度を 日本で実施し，430出来事のうち 24 の出来事は $90 \%$ 以上 の人がストレッサーだと見なすことを見いだしている。 また, 対処行動はストレッサーの性質や状況によって規 定される（大迫, 1994）以上, ストレッサーの性質を考 慮した対処行動研究は当然必要とされるであろう。

ところで対処の測定に関しては, 坂田 (1989) が簡潔 なレビューとともに Lazarus \& Folkman（1984）の問 題焦点型対処と情動焦点型対処などの分類を参考に，4 つのクラスターを含んだコーピング尺度を作成している。 また, 尾関・原口・津田 (1991) はコーピングが問題焦点 型, 情動焦点型, 回避・逃避型の 3 つに類型化されるこ とを見いだしている。これらの分類の観点と比較すると， 社会心理学における対人葛藤解決方略研究が情動焦点型 の対処を扱っていないことは明瞭である。対処は問題解 決機能と情動調節機能の両方がかかわり合っている複雑 なプロセスであり,そのパターンは，人的要因だけでも

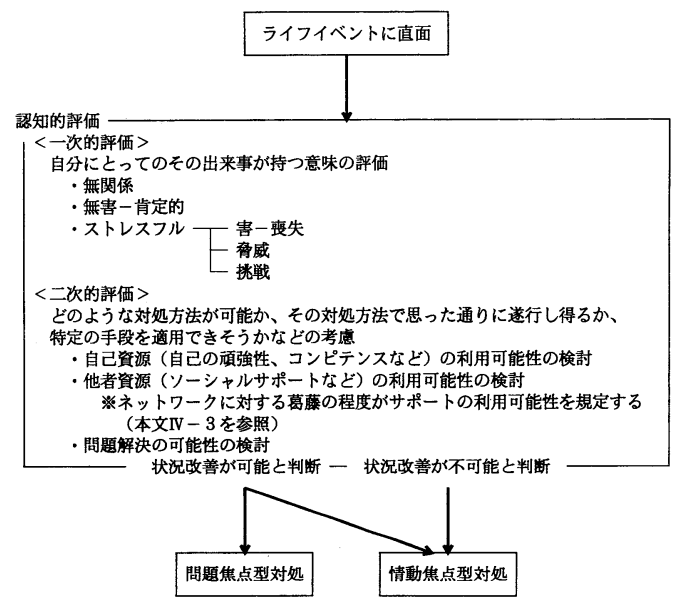

Figure 1. 対処方略決定までの評価過程.
状況要因だけでも決定できないものである（Folkman \& Lazarus, 1980)。また, Folkman (1984) によると, 人 はストレスフルな出来事を経験したとき, $98 \%$ が問題焦 点型と情動焦点型の対処を併用し, 状況が変化し得ると きには問題焦点型対処を増加させ, 状況が変化し得ない ときに情動焦点型対処を増加させる（Figure 1) ことが 明らかにされた。対人葛藤事態において葛藤対象との関 係によって対処方略は異なってくる（大迫・高橋, 1994 など）が, 例えば目上との葛藤で問題焦点型の対処は不 可能な状況でも，そこでは情動焦点型の対処が行われて いる可能性が充分考えられる。しかし, その対処行動が 問題解決のみならず，ストレス低減にどの程度有効なの かは明らかでないのが現状である。

\section{2. ソーシャルサポート研究における対人葛藤}

また, ストレス対処方略は問題焦点型/情動焦点型と いう次元による分類の他に，個人の持つ自己資源を用い るのか, 他者からの援助という他者資源を用いるのかと いう次元による分類も可能である。つまり, Figure 2 に 示すように対処方略は 2 次元上に配置することができる が, 後者の次元でいうところの他者からの援助による ストレス低減方略として注目を集めているのがソーシャ ルサポートである。ソーシャルサポートとは, 特定個人 が, 特定時点で, 彼/彼女と関係を有している他者から 得ている, 有形 / 無形の諸種の援助である（南・稲葉・ 浦，1988）。ソーシャルサポートは, Caplan（1974）な どの先駆的な研究以来, 抑㯺, ガン, 神経症, 仕事に対 する不満など, さまざまなストレッサーによって生じる ストレスを低減する（Barrera，1986）ことが知られて おり,わが国においても最近多くの研究が行われている (久田・千田・箕口, 1989 ; 南・稲葉・浦, 1988 ; 岡安・嶋 田・坂野, 1993; 嶋, 1991; 1992, 和田, 1989など)。なか

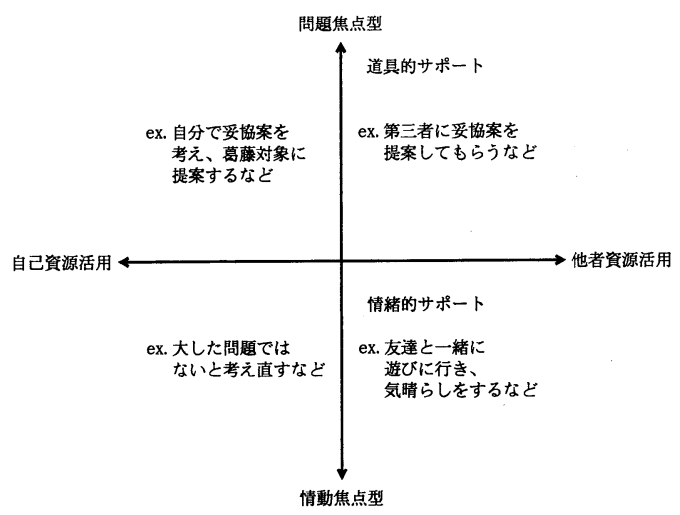

Figure 2. ストレス対処方略の次元. 
でも嶋（1992）は，対人葛藤を含んでいると考えられる 対人ストレスをソーシャルサポートが低減することを見 いだし, 対人葛藤対処方略としてのソーシャルサポート の有効性を示唆している。しかしながら，ソーシャルサ ポートと対人暮藤はともに同じ個人のソーシャルネット ワークの中で生起していながら, その関係は決して明確 ではない。対人関係においてサポートとストレスを同時 に扱う場合には，サポート提供者とストレスの原因（ス トレッサー）が別人の場合と同一人物の場合，さらに同 一人物の場合には, その人との葛藤と, それ以外のス卜 レッサーのどちらを低減すべきストレスの原因として設 定するのかを考えることが必要である (Figure 3)。こ の枠組みでいうと, 例えば嶋 (1992) の研究は, サポー 卜提供者とストレスの原因（ストレッサー）が別人の場 合という設定だと考えられる。先述した，社会的ジレン マ研究における第三者の介入もこれに該当するであろ う。また，サポート提供者とストレスの原因（ストレッ サー）が同一人物であることを想定した数少ない研究と して, Sandler \& Barrera（1984）の研究がある。彼ら はサポートネットワークを葛藤的なもの（サポートも提 供するが問題も生じさせる相互作用）と非葛藤的なもの （サポートを提供するのみの相互作用）に分類し, 葛藤 的なサポートネットワークは疾病兆候とポジティブに相 関し, ストレスと疾病兆候との間の関連を高めることを 見いだしている。ただし, 非葛藤的なネットワークにつ いては，疾病兆候を予測する効果はみられなかった。ま た Tilden \& Galyen (1987) は, 対人関係がサポートの 源であると同時にストレスの源でもあることを指摘し， 社会的交換理論と衡平理論の知見を導入した, ソーシャ ルサポートのコストと相互性尺度を作成している。しか し, ほとんどの研究ではサポートネットワークの葛藤的 側面は,「サポートに対する満足度」という言葉にすり 替えられ, 充分に考慮されていなかったのであるが, 近 年になってようやくサポートと葛藤の両面を含んだ尺度 を用いた研究が行われつつある (Pierce, Sarason, \& Sarason, 1991 ; 1992 ; Sarason, 1994)。そしてその中 で例えば Pierce et al. (1991) の研究では, サポートの 知覚と葛藤の知覚が負の相関を持つことが明らかにされ ている。しかし, この研究は尺度も対象を 1 人に限定し たものであり，また，対象に対する知覚がアンビバレン 卜な状態については触れていない。そもそも Figure 3 に示したような枠組みを明確にしている研究自体が少 なく,さらに対象が複数の場合の絡み合いなど, 同一の ソーシャルネットワークにおける対人葛藤とソーシャル サポートの関係は,またまた多くの疑問を残していると

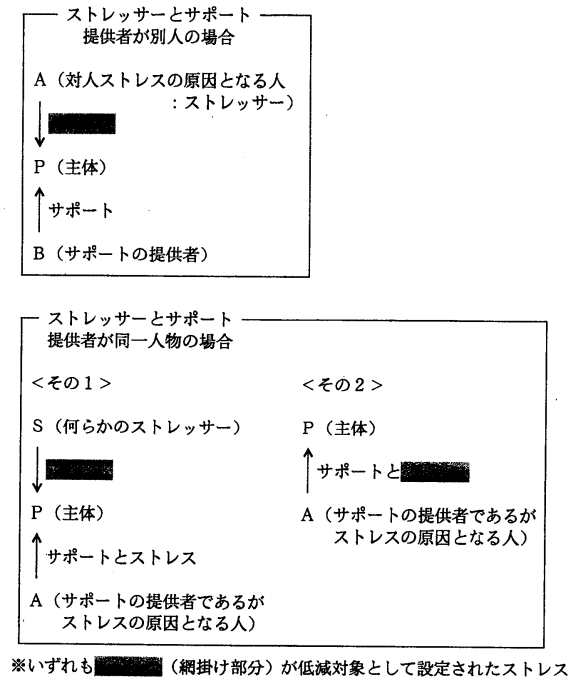

Figure 3. 対人ストレスとソーシャルサポートを含んだ 3 つの枠組み.

言えよう。

IV.「ストレッサーとしての対人葛藤」研究の今後の課 題と展望

以上のレビューから，ストレッサーとしての対人葛藤 を主題としている研究はほとんどないにもかかわらず, その近接領域での研究はかなり盛んに行われていること がうかがえる。つまり, 方法論的には既存の概念や知見 を基本的に踏襲しつつも, 心理社会的ストレス理論の枠 組みで対人葛藤というストレッサーの性質をより詳細に 検討していけば，新しい知見は充分に得られるはずであ る。その上で今後の具体的な課題としては, 以下の 3 点 が挙げられる。

\section{1. ストレッサーとしての対人葛藤の影響カ}

前述したように, 対人暮藤がストレッサーとなること はすでに多くの研究が示しているが, 対人活動のどの側 面が, どのようなストレス反応を引き起こすのかという 点までは明らかにされていない。考慮すべき変数として は, まず, 対人葛藤というストレッサーに特有の性質で ある, 葛藤対象との勢力関係やコミットメントの度合い などの関係性, そして池内（1971）の言うところの葛藤 行動の有無, 暮藤の志向性などが挙げられよう。そして これらの変数が Figure 1 における対処方略決定までの評 価過程において, 一次的評価と二次的評価の両方にどの ような影響を与えるのかを明らかにすることが今後の具 体的な課題のひとつと考えられる。

またストレス反応も, 情動的反応と認知・行動的反応 
とではその出現の仕方が異なる可能性も考えられる。具 体的には，葛藤行動が顕在化した対人葛藤と顕在化して いない葛藤とどちらの方がストレス反応に及ほす影響は 強いのか, 葛藤の対象や文脈によってストレス反応の種 類は異なるのかなどの疑問点が課題として存在する。し かしこの論点に関しては, ストレス研究のパラダイムに 乗るような葛藤場面の類型化や，ストレス反応全般に対 人葛藤が占める影響力の明確化など，精緻化すべき課題 が多く残されている。

\section{2. 対人葛藤対処方略のストレス低隇可能性}

ストレス対処方略に問題焦点型と情動焦点型があるこ とからも解るように，確かに問題解決のための対処方略 は同時にストレス低隇のための対処方略でもあるのだ が，その効力は決して明確ではない。例えば，相手を強 制的に従属させる対処方略が問題解決のためには最も有 効な場合でも，それを実行する個人が温和なパーソナリ ティならば，かえってその対処方略はストレス反応を増 加させることも充分に考えられる。また，例えば相手の 勢力が非常に強い場合などといった，葛藤対象との関係 によっては問題焦点型よりも情動焦点型の方がストレス 低隇に有効なケースも想定されるが, 対人葛藤という特 定されたストレッサーに対して問題焦点型と情動焦点型 の両対処方略を視野に入れた研究はあまりないのが現状 である。さらに, 情動焦点型対処にもさまざまなものが 考えられ, ソーシャルサポートを含めて, 問題解決のみ ならずストレス低隇の側面からも対人葛藤によるストレ スを低滅する対処方略の模索が必要であろう。そのため には, 問題解決とストレス低減という 2 つの従属変数を 弁別した上で, 個々の対処方略を別個に検討する枠組み を持つ研究が必要である。もちろんその際, 問題解決と ストレス低隇がどの程度共変するかを検証することが必 要であるのは言うまでもない。

\section{3. ソーシャルサポートと対人萬藤との関連}

個人のソーシャルネットワークは対人葛藤の源である と同時に, ソーシャルサポートの源でもある。しかしこ の両側面を視野に入れた具体的な議論はあまり行われず， それぞれを別個に考える研究が多いのが現状である。こ の両者を包括的に捉えた研究としては利益 (benefit) と 損失 (cost) という概念を用いた社会的交換理論や衡平 理論などを導入したものがあり,これらの研究は現実場 面に即しているとは言い難い実験室的性質を持っている が, 多くの変数を媒介する心理的ストレス理論とも共通 する側面もある。なぜなら, 心理的ストレス理論は, 精 神・身体的なホメオスタシスが崩れたとき，それを回復 するためにさまざまな対処方略が行われるという考え方
である。そしてホメオスタシスが保たれている状態を利 益と損失のバランスが保たれている状態と考えれば，対 処方略は衡平を回復するための努力とも考元られるから である。しかし，抽象度の高いこの理論を現実場面に適 用させる際には，何がその人にとって利益となるのか， 何が同じく損失なのかを明確にすることが不可欠である。 また，利益と損失のバランスをネットワーク全体のみな らず，個々のネットワーク成員との関係について検討す る必要もあろう。さらに, 利益と損失のバランスが, 問 題解決もしくはストレス低減という従属変数とどのよう に結びつくのかも検討の対象であり, 理論の実証に至る までには多くの課題が残されている。

しかし，いずれにせよストレス低隇という臨床的な課 題において，それぞれ基本的に逆の役割を果たす対人葛 藤とソーシャルサポートは, ソーシャルネットワークの中 でどのように重なり合い, どのように相互牽制している のか, そして理想的な対人関係とはどのような形態なの かというテーマは充分議論するに值すると思われる。そ して, この論点を明らかにするためのモデルの例として, 対人葛藤を，偶発性を含んだ対人関係で実際に起こった トラブルと, 安定した認知が形成されている, 他者資源 利用可能性の規定要因とに区別することが考えられる。 このような概念化によって, 前者は Figure 1 でいうとこ ろの直面したライフイベント, 後者は同じく二次的評価 における他者資源を規定する変数として考えることが可 能となる。また, Figure 3 の下図その 1 （ストレッサー とサポート提供者が同一人物の場合）で言えば，前者は $\mathrm{S}$ (何らかのストレッサー) であり，後者は A がサポー トとともに同時に提供するストレスである。この枠組み を用いれば，対人葛藤というストレッサーにソーシャル サポートがどれだけ有効かという論点とともに，葛藤的 な対人関係がどれだけサポートの効力を制限するかとい う論点も検証可能となり得ると考えられる。

そのほかにも, 本論文では特に触れなかったが, 対人 葛藤における対処方略の選択には文化差, 対人相互作用 の目標, パーソナリティなどが介在することも明らかに されている(大迫・高橋, 1994)。具体的には例えばパー ソナリティについて, Sternberg \& Soriano（1984）は, 1 人の個人においては用いられる対処方略にかなり一貫 性があること，また，その対処方略はその個人のパーソ ナリティからある程度推測可能なことを指摘している。 しかし対人葛藤におけるパーソナリティの影響と一口に 言っても, 対人関係が生起する段階, 認知的評価を行う 段階, 対処方略の実行段階, 問題解决・ストレス反応な ぞの結果が現れる段階のそれぞれでパーソナリティの影 
響は常に介在すると考えられる。そして, 今日までの研 究は対処方略の選択におけるパーソナリティの影響の議 論にとどまっており，パーソナリティなどの内的特性が， 本論文の主題である問題解決やストレス低減までの各段 階で，それぞれどう影響するかは今後に残された検討課 題であろう。一方, Rook（1984）は，パーソナリティな どの個人の内的特性よりも, 関係の内容を重視する必要 を指摘しており，これらの比重についても明らかではな い。また, 発達文化的側面に関して言えば，現代の青年 は他者との摩擦（暮藤行動が顕在化する対人葛藤）を回 避するのがうまい反面，(葛藤行動が顕在化しない）対人 葛藤によるストレスを個人内に多く抱えている傾向があ るということがしばしば指摘されており（千石，1994； 鶴田・森田，1992など），統計的手法を用いた研究によ る実証とその対策が望まれる。今日わが国において重大 な社会問題となっている，青少年のいじめなどに関して も, 表面的な問題解決のみならず, その深層にある心理 的な歪みを取り除くことが必要なのではないか。そのよ うな意味においても, 対人葛藤をストレッサーとして捉 える研究の今後の更なる発展が望まれる。

\section{引用文献}

Barrera, M., Jr. 1986 Distinctions between social support concepts, measures, and models. American Journal of Community Psychology, 14, 413-445.

Braver, S. L., \& Rohrer, V. 1978 Superiority of vicarious over direct experience in interpersonal conflict resolution. Journal of Confict Resolution, 22, 143-155.

Caplan, G. 1974 Support systems and community mental health. New York: Behavioral Publications.

Falbo, T., \& Peplau, L. A. 1980 Power strategies in intimate relationships. Journal of Personality and Social Psychology, 38, 618-628.

Folkman, S. 1984 Personal control and stress and coping processes: A theoretical analysis. Journal of Personality and Social Psychology, 46, 839-852.

Folkman, S., \& Lazarus, R. S. 1980 An analysis of coping in a middle-aged community sample. Journal of Health and Social Behavior, 21, 219-239.

藤森立男 1987 対人葛藤の解決ストラテジーについ ての研究 日本グループ・ダイナミックス学会第35 回大会発表論文集，67-68.

藤森立男 1989 日常生活にみるストレスとしての対 人葛藤の解決過程に関する研究 社会心理学研究,
4, 108-116.

藤森立男・藤森和美 1992 人と争う 松井 豊（編） 対人心理学の最前線 サイエンス社 Pp. 141-151.

久田 満・千田茂博・箕口雅博 1989 学生用ソーシャ ル・サポート尺度作成の試み（1）日本社会心理 学会第30回大会発表論文集, 143-144.

Holmes, T. H., \& Rahe, R. H. 1967 The social readjustment rating scale. Journal of Psychosomatic Research, 11, 213-218.

Hoskins, C. N. 1978 A study of the relationship between level of activation, body temperature and interpersonal conflict in family relationships. Dissertation Abstracts International, 39, 139.

池内 一 1971 コンフリクトの社会心理学 日本社 会心理学会 (編) 葛藤と紛争一年報社会心理学・第 12号一 勁草書房 Pp. 8-35.

梶田㩚一 1988 自己意識の心理学（第 2 版） 東京大 学出版会

Kilmann, R. H., \& Thomas, K. W. 1977 Developing a forced-choice measure of conflict handling behavior: The "MODE" instruments. Educational and Psychological Measurement, 37, 309-325.

Last, C. G., Barlow, D. H., \& O'Brien, G. T. 1984 Precipitants of agoraphobia: Role of stressful life events. Psychological Reports, 54, 567-570.

Lazarus, R. S., \& Folkman, S. 1984 Stress, appraisal, and coping. New York: Springer. （ラザルス R. S., フォルクマン S. 本明 寛・春木 豊・織田正 美 監訳 1991 ストレスの心理学一認知的評価と 対処の研究一 実務教育出版)

Mack, R. W., \& Snyder, R. C. 1957 The analysis of social conflict: Toward an overview and synthesis. Journal of Conflict Resolution, 1, 212-248.

南 隆男・稲葉昭英・浦 光博 1988 「ソーシャル・ サポート」研究の活性化に向けて一若干の資料一 哲学, 85, 151-184.

本明 寛 1990 健康心理学に期待するもの 社会心 理学研究, 5, 75-82.

岡安孝弘・沜田洋徳・坂野雄二 1993 中学校における ソーシャル・サポートの学校ストレス軽減効果 教 育心理学研究, 41, 302-312.

大迫秀樹 1994 高校生のストレス対処行動の状況によ る多様性とその有効性 健康心理学研究, 7, 26-34. 大迫弘江・高橋 超 1994 対人的葛藤事態における対 人的感情及び葛藤処理方略に及ぽ「甘え」の影響 
実験社会心理学研究，34，44-57.

尾関友佳子・原口雅浩・津田 彰 1991 大学生の生活

ストレッサー, コーピング, パーソナリティとスト

レス反応 健康心理学研究, 4, 1-9.

Pierce, G. R., Sarason, B. R., \& Sarason, I. G. 1992

General and specific support expectations and stress as predictors of perceived supportiveness:

An experimental study. Journal of Personality and Social Psychology, 63, 297-307.

Pierce, G. R., Sarason, I. G., \& Sarason, B. R. 1991 General and relationship-based perceptions of social support: Are two constructs better than one? Journal of Personality and Social Psychology, 61, 1028-1039.

Rahim, M. A. 1983 A measure of styles of handling interpersonal conflict. Academy of Management Journal, 26, 368-376.

Rook, K. S. 1984 The negative side of social interaction: Impact on psychological well-being. Journal of Personality and Social Psychology, 46, 10971108.

坂田成輝 1989 心理的ストレスに関する一研究一コー ピング尺度 (SCS) の作成の試み一 早稲田大学教 育学部学術紀要（教育・社会教育・教育心理・体育 学編)，38, 61-72.

Sandler, I. N., \& Barrera, M., Jr. 1984 Toward a multimethod approach to assessing the effects of social support. American Journal of Community Psychology, 12, 37-52.

Sarason, I. R. 1994 Future directions in social support research. Proceedings of the Japan-U.S. Conference on Social Support, 1-37.

千石 保 1994 マサツ回避の世代一若者のホンネと 主張一PHP 研究所

Sillars, A. L. 1980 Attributions and communication in roommate conflicts. Communication Monographs, 47, 180-200.

嶋 信宏 1991 大学生のソーシャルサポートネット ワークの測定に関する一研究 教育心理学研究, 39, 440-447.

嶋 信宏 1992 大学生のソーシャルサポートネット ワークの日常生活ストレスに対する効果 社会心 理学研究, 7, 45-53.

Sternberg, R. J., \& Soriano, J. L. 1984 Styles of conflict resolution. Journal of Personality and Social Psychology, 47, 115-126.

Tilden, V. P., \& Galyen, R. D. 1987 Cost and conflict: The dark side of social support. Western Journal of Nursing Research, 9, 9-18.

鶴田和美・森田美弥子 1992 キャンパスにおける心の 成長一自分らしさを求めて一 田畑 治·蔭山英順・ 小嶋秀夫（編） 現代人の心の健康一ライフサイク ルの視点から一 名古屋大学出版会 Pp. 92-106.

浦 光博 1992 支えあう人と人一ソーシャルサポー 卜の社会心理学一 サイエンス社

Warehime, R. G., \& Lowe, D. R. 1983 Assessing assertiveness in work settings: A discrimination measure. Psychological Reports, 53, 1007-1012.

和田 実 1989 ソーシャル・サポート (Social Support) に関する一研究 東京学芸大学紀要 (第 1 部門), 40, 23-38.

八尋華那雄・井上眞人・野沢由美佳 1993 ホームズら の社会的再適応評価尺度（SRRS）の日本人におけ る検討 健康心理学研究, 6, 18-32.

山岸俊男 1990 社会的ジレンマのしくみ一「自分 1 人ぐらい」の心理の招くもの一サイエンス社

吉野絹子 1987 対人的葛藤の解決過程の分析 (1)一葛 藤に関する反応パターンとその類型化一 社会心 理学研究, 2, 35-44. 


\section{Interpersonal Conflicts as Stressors: A Perspective for Stress Reduction Strategies}

\section{TAKESH HASHimoto (Nagoya University)}

Social psychological researches on interpersonal conflicts have been trying to discover the available problem-solving strategies. However these have not been enough discussed on the psychological stress, which accompany with interpersonal conflicts, and stress reduction of them. On the other hand, in the area of health psychology, though interpersonal conflicts have been studied as stressors, these specificity have not been considered sufficiently. The purpose of this paper is to review the findings on interpersonal conflicts and coping strategies in these areas and to propose the study which integrates them. Relations between interpersonal conflicts and social support, which comes from the same social network, were also discussed. The following factors were suggested for further study; (1) The effect of interpersonal conflicts as stressors. (2) The possibility of stress reduction by interpersonal conflict coping strategies. (3) The relation between social support and interpersonal conflict. The necessity to distinguish between life events which occur accidentally and social cognition which is relatively stable was claimed

Key words: interpersonal conflicts, stressors, problem-solving (coping) strategies, appraisal and coping theory of psychological-social stress, social support 